\title{
MRI-semiotics of the gluteal muscles in patients with avascular necrosis of the femoral head and Legg-Calve-Perthes disease
}

\author{
G.V. Diachkova, M.P. Teplenky, K.A. Diachkov, T.A. Larionova
}

Russian Ilizarov Scientific Center for Restorative Traumatology and Orthopaedics, Kurgan, Russian Federation

\begin{abstract}
Objective To explore the gluteal muscles in patients with avascular necrosis of the femoral head and Legg-Calve-Perthes disease using magnetic resonance imaging (MRI). Material and methods MRI was used to examine gluteal muscles in 20 patients with avascular necrosis of the femoral head and Legg-Calve-Perthes disease. There were 8 female and 12 male patients aged from 6 to 18 years. Results The extent of MRI changes detected in femoral abductors of patients with avascular necrosis of the femoral head and Legg-Calve-Perthes disease was dependent on the grade and onset of the disease and patient age. There were differences found in thickness, length and area of the m. gluteus maximus, m. gluteus medius and $\mathrm{m}$. gluteus minimus in unilateral involvement. Maximum changes were revealed in children aged 14-17 years with grades 3 and 4 of the disease. There was a greater decrease in length of m. gluteus minimus as compared to that of $\mathrm{m}$. gluteus medius. Conclusion The findings revealed anatomical (area, thickness, length) and radiomorphological changes in the gluteal muscles of patients with avascular necrosis of the femoral head and Legg-Calve-Perthes disease that were dependent on the grade and onset of the disease and patient age, and indicated to close relationship between anatomy and function of the joint and muscles.
\end{abstract}

Keywords: hip joint, avascular necrosis of the femoral head, Legg-Calve-Perthes disease, gluteal muscles, MRI

\section{INTRODUCTION}

Although juvenile osteochodrosis of the femoral head (Legg-Calvé-Perthes disease) and avascular bone necrosis have been studied extensively for at least 100 years there are still controversies in etiology of the disease and optimal treatment of the condition [1-8]. Changes in the femoral head in Legg-Calvé-Perthes disease and avascular necrosis evaluated with imaging modalities (MSCT, MRI, US) are well described at different stages of the disease [9-11]. MRI provides good visualization of the cartilage of the femoral head and evaluation of the genuine shape of the proximal femur, severity of extrusion and superior lateral capital displacement, and condition of the articular labrum. Subchondral fracture can be identified at early stages [12-17]. There are studies reporting of normal picture of the soft tissues surrounding the hip joint and the osseous components examined with MRI and MSCT [18, 19]. Contractility of thigh muscles with biomechanically disturbed functioning was studied in patients with hip pathologies as well as condition of lower limb muscles in children with affected hip [20,21]. However, there have been no studies that would quantitavely examine gluteal muscles in pediatric hip pathologies using MRI. Nevertheless, there are studies describing hypotrophy or atrophy of gluteal or thigh muscles in Perthes disease [12, 22-24].

\section{MATERIAL AND METHODS}

Magnetic resonance imaging was performed for 20 patients with avascular necrosis of the femoral head and Legg-Calvé-Perthes disease. The patients' age ranged from 5 years to 16 years prior to the treatment. Two patients had bilateral involvement. MRI was performed with a $1.5 \mathrm{~T}$ unit (Siemens Magnetom Symfony). T2 tse and $\mathrm{t} 1 \mathrm{fl} 2 \mathrm{~d}$ coronal, axial and sagittal images of the hip joints were obtained with or without fat suppression to measure gluteal thickness, length and area and compare MR-signal with contralateral side (Fig. 1).
The study was performed in accordance with ethical principles for medical research involving human subjects stated in the Declaration of Helsinki developed by the World Medical Association as revised in 2000 and Order No. 266 of June 19, 2003 On Approval of Rules of Good Clinical Practice in the Russian Federation. Written informed consent was obtained from all patients and their legal representatives for publication of the findings without identifying details.

Diachkova G.V., Teplenky M.P., Diachkov K.A., Larionova T.A. MRI-semiotics of the gluteal muscles in patients with avascular necrosis of the femoral head and Legg-Calve-Perthes disease. Genij Ortopedii, 2019, vol. 25, no 4, pp. 481-486. DOI 10.18019/10284427-2019-25-4-481-486. (In Russian) 


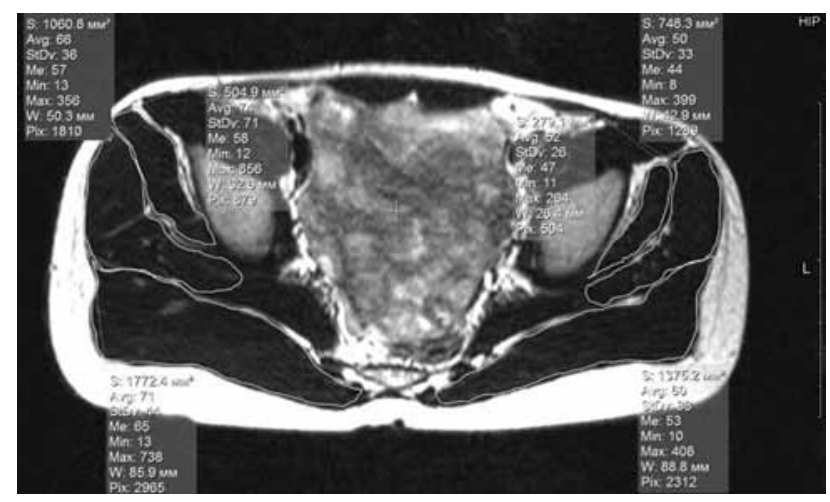

Fig. 1 MR T2WI axial image of the hip joints of a 5-yearold patient $M$. with Legg-Calvé-Perthes disease showing measurements of an area and relative density of gluteal muscles
Statistical data analysis was performed using Microsoft EXCEL-2010 and Attestat-2001 computer program. The Shapiro-Wilk test was used to examine normal distribution in a population. We performed Student $\mathrm{t}$ test for normally distributed variables and nonparametric Mann-Whitney U-test and Wilcoxon rank-sum test for variables that were not normally distributed. We set the significance threshold at 0.05 . The research was performed as a restrospective unicenter fulldesign study.

RESULTS

Changes in gluteal muscles of patients with LeggCalvé-Perthes disease and avascular bone necrosis were characterized by general manifestations taking into consideration general etiological factors and clinical features. An area and thickness of muscles appeared to decrease as compared to the normal side. An extent of changes was dependent on severity of destruction of the femoral head, presence of limb shortening, onset of the disease, presence of pathology in the contralateral side. The older the patient the greater decrease in the muscle area was observed (Fig. 2).

Table 1 presents an area of gluteal muscles in patients with Legg-Calvé-Perthes disease depending on patient's age and stage of the disease.

Decreased length of $\mathrm{m}$. gluteus medius and m. gluteus minimus was observed in coronal MR images. Measurements of the $\mathrm{m}$. gluteus minimus showed greater decrease in length that the $\mathrm{m}$. gluteus medius as compared with the contralateral side of all patients. Figure 3 demonstrates the length of the $\mathrm{m}$. gluteus medius and the m.gluteus minimus on the left (pathologically changed femoral head) being decreased by $14.0 \%$ and $31.4 \%$, respectively.
Changes in the muscles' length were likely to be associated with hypotrophic and short muscles.

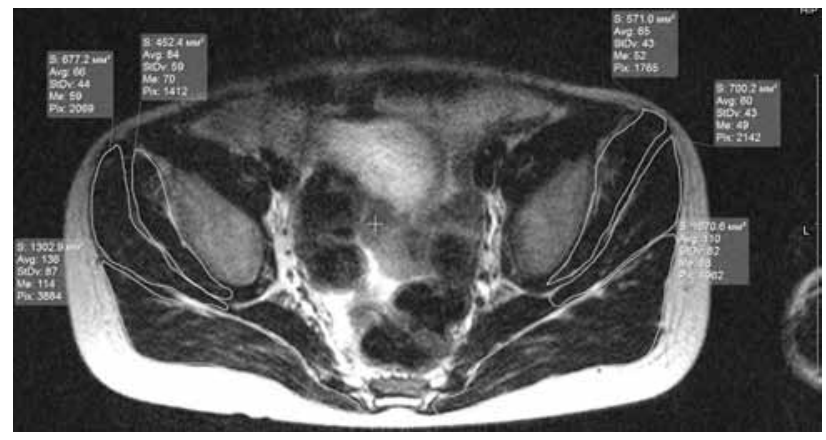

Fig. 2 MR T2-tse axial image of the hip joints of an 8-yearold patient M. with grade 2 Legg-Calvé-Perthes disease showing measurements of an area of $\mathrm{m}$. gluteus maximus, $\mathrm{m}$. gluteus medius and $\mathrm{m}$. gluteus minimus. A decrease in area of the right-side m. gluteus minimus was $20.8 \%$, m.gluteus medius, $3.3 \%$ and m.gluteus maximus $22.1 \%$

Alterations in the thickness of the $\mathrm{m}$. gluteus medius and the m.gluteus minimus were more expressed in unilateral involvement with a longer period of the disease and more considerable changes identified in the femoral head. Maximal changes were observed in patients aged 13 years and over, 15-16 years, in particular, and with grade III of the disease (Fig. 4, 5).

Table 1

Area of gluteal muscles in patients with Legg-Calvé-Perthes disease depending on patient's age and stage of the disease $\left(\mathrm{mm}^{2}\right)$

\begin{tabular}{|l|c|c|c|c|c|c|}
\hline \multirow{2}{*}{ Site of interest } & \multicolumn{6}{|c|}{ Stage of the disease } \\
\cline { 2 - 7 } & \multicolumn{7}{|c|}{2} & \multicolumn{4}{|c|}{ Age } \\
\cline { 2 - 7 } & $5-8$ & $9-12$ & $13-16$ & $5-8$ & $9-12$ & $13-16$ \\
\hline $\begin{array}{l}\text { Musculus gluteus } \\
\text { maximus }\end{array}$ & $1302 \pm 186.6$ & $1588.9 \pm 234.4$ & - & $1248.4 \pm 175.1$ & $1548 \pm 211.1$ & $1856.7 \pm 475.6$ \\
\hline $\begin{array}{l}\text { Musculus gluteus } \\
\text { medius }\end{array}$ & $677 \pm 92.7$ & $1341.3 \pm 132.6$ & - & $699.8 \pm 85.5$ & $1246.7 \pm 117.2$ & $1499.3 \pm 278.1$ \\
\hline $\begin{array}{l}\text { Musculus gluteus } \\
\text { minimus }\end{array}$ & $452 \pm 56.1$ & $577.4 \pm 48.6$ & - & $472.9 \pm 56.2$ & $347.5 \pm 98.7$ & $896.9 \pm 17.5$ \\
\hline
\end{tabular}


Genij Ortopedii, Vol. 25, no 4, 2019

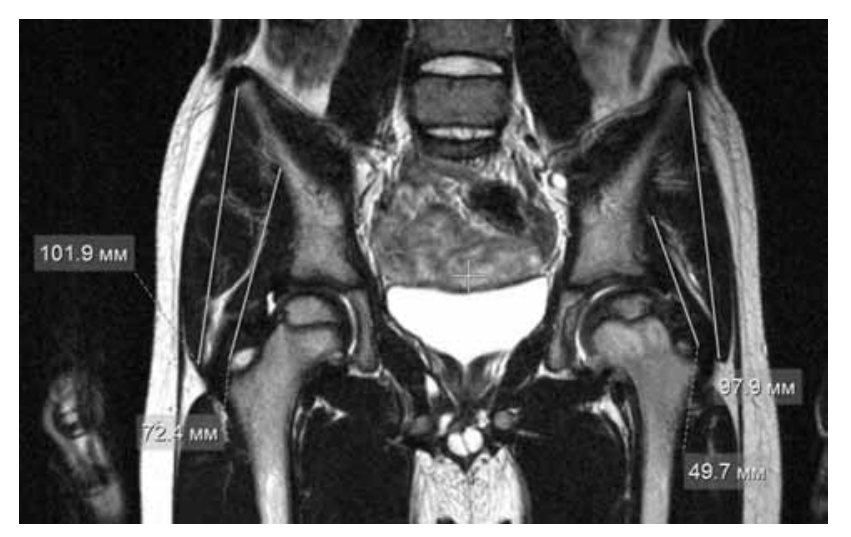

Fig. 3 MR T2WI coronal image of the hip joints of a 5-year-old patient $M$. with grade 3 Legg-Calvé-Perthes disease showing length measurements of the $\mathrm{m}$. gluteus medius and the $\mathrm{m}$. gluteus minimus

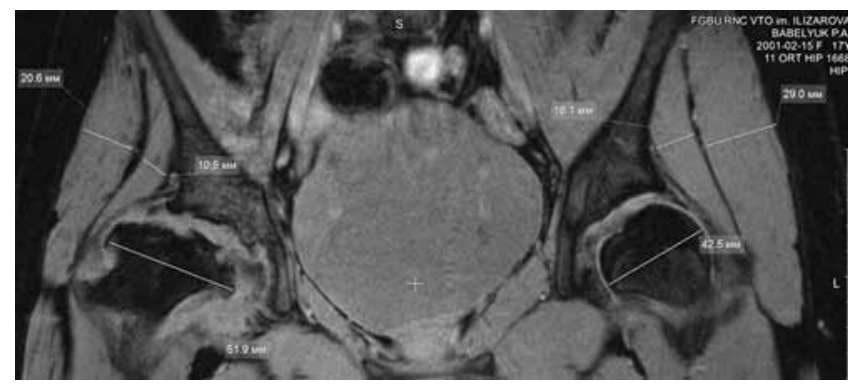

Fig. 4 Postoperative MR t2-fl2d fs coronal image of the hip joints of a 17-year-old patient B. with grade 4 avascular necrosis of the femoral head on the right, grade $3 \mathrm{DOA}$ showing measurements of thickness of the $\mathrm{m}$. gluteus medius and the $\mathrm{m}$. gluteus minimus. M. gluteus medius and the $\mathrm{m}$. gluteus minimus on the left appeared to be thicker by $29.0 \%$ and $34.8 \%$, respectively

Radiomorphological manifestations of impaired muscle structures were clearly observed with considerably increased distance and altered direction

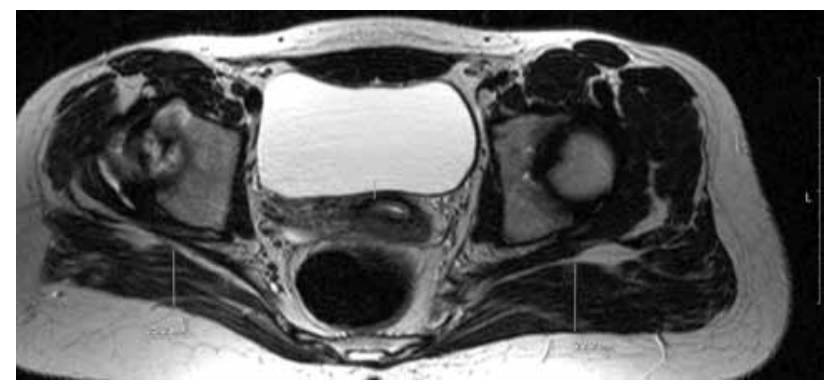

Fig. 5 Postoperative MR t2-fl2d fs axial image of the hip joints of a 17-year-old patient B. with grade 4 avascular necrosis of the femoral head on the right, grade $3 \mathrm{DOA}$ showing measurements of thickness of the m. gluteus maximus that appeared to be thinner than that on the left by $16.7 \%$.

between muscle fibres, alterations in signal muscle intensity in addition to changes in anatomical characteristics (length, thickness, shape).

\section{DISCUSSION}

Early detection of avascular bone necrosis of the femoral head and Legg-Calvé-Perthes disease using a variety of imaging modalities constitutes an important objective [9, 10, 17, 25-27]. MRI can be useful early in the disease's course in order to change the clinical scenario of avascular necrosis of the femoral head and Legg-Calvé-Perthes disease, provide the possibility of multiple monitoring of the condition, visualize osseous and soft tissue structures of the hip joint and verify presence of synovitis [11]. Hip evaluation protocols have been suggested at suspicion of inflammation in the femoral head to identify localization and dimension of necrosis, integrity of articular surfaces and subchondral fractures with MRI-semiotics of stages of the disease properly studied [10, 15, 17, 27-29]. Unfortunately, there are very few publications describing changes in the para-articular tissues of the hip and there is no evidence of gluteal muscles' condition having a significant role in the hip function [11, 12, 14, 24, 30]. Multiple studies focus on close relationship between the anatomy and biomechanics of the gluteal muscles and the hip joint and the spine [22, 30-34]. It is difficult to suggest that expressed changes in the hip, limited range of motion in the joint, decreased weight-bearing would not result in disturbed structure and function of the hip abductor muscles [22, 35, 36]. The extent of MRI changes detected in femoral abductors of patients with avascular necrosis of the femoral head and Legg-Calve-Perthes disease was dependent on the grade and onset of the disease and patient age. There were differences found in thickness, length and area of the m. gluteus maximus, $\mathrm{m}$. gluteus medius and m. gluteus minimus in unilateral involvement. Maximum changes were revealed in children aged 14-17 years with grades 3 and 4 of the 
disease. There was a greater decrease in length of the $\mathrm{m}$. gluteus minimus as compared to that of the $\mathrm{m}$. gluteus medius. Our previous studies of the gluteal muscles evaluated in different pathologies as well researches performed by different authors allow us to suggest that the gluteal muscles can be employed for screening detection of a hip pathology in absence of radiological evidence of the condition or can indicate to the necessity of rehabilitation of the affected joint since the muscle reaction to the limited range of motion and decreased weight-bearing on the joint with pain are most likely to rapidly lead to hypotrophy of the $\mathrm{m}$. gluteus medius and the $\mathrm{m}$. gluteus minimus [31, 33, 34, 36, 37].

\section{CONCLUSION}

The findings revealed anatomical (area, thickness, length) and radiomorphological changes in the gluteal muscles of patients with avascular necrosis of the femoral head and Legg-Calve-Perthes disease that were dependent on the grade and onset of the disease and patient age, and indicated to close relationship between.

\section{REFERENCES}

1. Teplenky M.P., Parfenov E.M. Khirurgicheskoe lechenie detei s tiazhelymi formami bolezni Pertesa [Surgical treatment of children with severe forms of Perthes disease]. Genij Ortopedii, 2013, no. 1, pp. 32-35. (in Russian)

2. Bunov V.S., Teplenky M.P., Oleinikov E.V. Osobennosti gemodinamiki v sheike bedrennoi kosti u detei s asepticheskim nekrozom golovki bedra [Characteristic features of hemodynamics in femoral neck of children with femoral head aseptic necrosis]. Genij Ortopedii, 2016, no. 4, pp. 50-55. (in Russian) DOI 10.18019/1028-4427-2016-4-50-55.

3. Borodin S.V., Volkov E.E., Gordeev M.V., Goloshchapov A.P. Faktornyi analiz biokhimicheskikh i klinicheskikh pokazatelei asepticheskogo nekroza golovki bedrennoi kosti [Factor analysis of biochemical and clinical indicators of aseptic necrosis of the femoral head]. Genij Ortopedii, 2018, vol. 24, no. 4, pp. 487-491. (in Russian) DOI 10.18019/1028-4427 2018-24-4487-491.

4. Barsukov D.B., Kamosko M.M. Konservativnoe i khirurgicheskoe lechenie detei s bolezniu Legga-Kalve-Pertesa [Conservative and surgical treatment of children with Legg-Calvé-Perthes disease]. Mironov S.P., ed. Travmatologiia $i$ ortopediia detskogo $i$ podrostkovogo vozrasta. Klinicheskie Rekomendatsii [Traumatology and Orthopaedics of Children and Adolescent Age. Clinical Recommmendations]. M., GEOTAR-Media, 2017, ch. 6, pp. 122-138. (in Russian)

5. Ibrahim T., Little D.G. The Pathogenesis and Treatment of Legg-Calvé-Perthes Disease. JBJS Rev., 2016, vol. 4, no. 7, pii: 01874474201607000-00003. DOI: 10.2106/JBJS.RVW.15.00063.

6. Chaudhry S., Phillips D., Feldman D. Legg-Calvé-Perthes disease: an overview with recent literature. Bull. Hosp. Jt. Dis. (2013), 2014, vol. 72, no. 1, pp. 18-27.

7. Mullan C.J., Thompson L.J., Cosgrove A.P. The Declining Incidence of Legg-Calve-Perthes' Disease in Northern Ireland: An Epidemiological Study. J. Pediatr. Orthop., 2017, vol. 37, no. 3, pp. e178-e182. DOI: 10.1097/BPO.0000000000000819.

8. Zhao L., Kaye A.D., Kaye A.J., Abd-Elsayed A. Stem Cell Therapy for Osteonecrosis of the Femoral Head: Current Trends and Comprehensive Review. Curr. Pain Headache Rep., 2018, vol. 22, no. 6, pp. 41. DOI: 10.1007/s11916-018-0700-x.

9. Vasilev A.Iu., Karpov S.S. Analiz effektivnosti primeneniia tomosinteza pri diagnostike osteokhondropatii golovki bedrennoi kosti (bolezn Legga-Kalve-Pertesa) [Analysis of the effectiveness of using tomosynthesis when diagnosing osteochondropathy of femoral head (Legg-Calvé-Perthes disease)]. Almanakh Klinicheskoi Meditsiny, 2017, vol. 45, no. 1, pp. 14-22. (in Russian) Available at: https:// doi.org/10.18786/2072-0505-2017-45-1-14-22.

10.Maranho D.A., Nogueira-Barbosa M.H., Zamarioli A., Volpon J.B. MRI abnormalities of the acetabular labrum and articular cartilage are common in healed Legg-Calvé-Perthes disease with residual deformities of the hip. J. Bone Joint Surg. Am., 2013, vol. 95, no. 3, pp. 256-265. DOI: 10.2106/JBJS.K.01039.

11.Robben S.G., Meradji M., Diepstraten A.F., Hop W.C. US of the painful hip in childhood: diagnostic value of cartilage thickening and muscle atrophy in the detection of Perthes disease. Radiology, 1998, vol. 208, no. 1, pp. 35-42. DOI: 10.1148/ radiology.208.1.9646790.

12.Kim H.K., Wiesman K.D., Kulkarni V., Burgess J., Chen E., Brabham C., Ikram H., Du J., Lu A., Kulkarni A.V., Dempsey M., Herring J.A. Perfusion MRI in Early Stage of Legg-Calvé-Perthes Disease to Predict Lateral Pillar Involvement: A Preliminary Study. J. Bone Joint Surg. Am., 2014, vol. 96, no. 14, pp. 1152-1160.

13.Shirai Y., Wakabayashi K., Wada I., Tsuboi Y., Ha M., Otsuka T. MRI appearance in the early stage of Legg-Calvé-Perthes disease to predict lateral pillar classification: A retrospective analysis of the labral horizontalization. J. Orthop Sci., 2018, vol. 23, no. 1, pp. 161-167. DOI: 10.1016/j.jos.2017.11.009.

14.Dimeglio A., Canavese F. Imaging in in Legg- Calvé -Perthes disease. Orthop. Clin. North Am., 2011, vol. 42, no. 3, pp. $297-302$. DOI: 10.1016/j.ocl.2011.04.003.

15.Wu W.. He W., Wei Q.S., Chen Z.Q., Gao D.W., Chen P., Zhang Q.W., Fang B., Chen L.L., Li B.L. Prognostic analysis of different morphology of the necrotic-viable interface in osteonecrosis of the femoral head. Int. Orthop., 2018, vol. 42, no. 1, pp. 133-139. DOI: $10.1007 / \mathrm{s} 00264-017-3679-8$. 
16.Bohndorf K., Roth A. Imaging and classification of avascular femoral head necrosis. Orthopade, 2018, vol. 47, no. 9, pp. $729-734$. DOI: 10.1007/s00132-018-3615-7.

17.Trăistaru M.R., Kamal D., Kamal K.C., Rogoveanu O.C., Popescu M., Bondari S., Alexandru D.O., Ionovici N., Grecu D.C. Imaging and histopathological aspects in aseptic osteonecrosis of the femoral head. Rom. J. Morphol. Embryol., 2015, vol. 56, no. 4, pp. 1447-1453.

18.Diachkova G.V., Korabelnikov M.A., Diachkov K.A. Kolichestvennye parametry otsenki metodami kompiuternoi i magnitnorezonansnoi tomografii normalnoi kartiny miagkotkannogo komponenta tazobedrennogo sustava [Quantitative evaluation parameters of the normal picture of the hip soft-tissue component using CT and MRI technique]. Genij Ortopedii, 2010, no. 2, pp. 91-95. (in Russian)

19.Diachkova G.V., Korabelnikov M.A., Diachkov K.A. Kolichestvennye parametry otsenki metodami kompiuternoi i magnitnorezonansnoi tomografii vertluzhnoi vpadiny i golovki bedrennoi kosti u patsientov razlichnogo vozrasta [Quantitative evaluation parameters of acetabulum and femoral head using CT and MRI in patients of different age groups]. Genij Ortopedii, 2009, no. 2, pp. 131-135. (in Russian)

20.Oleinikov E.V., Dolganova T.I., Dolganov D.V., Teplenky M.P. Sokratitelnaia sposobnost myshts bedra pri biomekhanicheskikh narusheniiakh uslovii ikh funktsionirovaniia u patsientov s patologiei tazobedrennogo sustava [Contractility of femoral muscles for biomechanical disorders of their functioning conditions in patients with the hip pathology]. Genij Ortopedii, 2012, no. 3, pp. 94-96. (in Russian)

21.Krivonogova Z.M., Saifutdinov M.S., Teplenky M.P. Sostoianie myshts nizhnikh konechnostei u detei s zabolevaniiami tazobedrennogo sustava $\mathrm{v}$ protsesse lecheniia metodom chreskostnogo osteosinteza [The condition of lower limb muscles in children with the hip diseases in the process of treatment by transosseous osteosynthesis method]. Genij Ortopedii, 2007, no. 1, pp. 42-47. (in Russian)

22.Kozhevnikov O.V., Lysikov V.A., Ivanov A.V. Bolezn Legg-Kalve-Pertesa: etiologiia, patogenez, diagnostika i lechenie [LeggCalvé-Perthes disease: etiology, pathogenesis, diagnosis and treatment]. Vestnik Travmatologii i Ortopedii im. N.N. Priorova, 2017, no. 1, pp. 77-87. (in Russian)

23.Kozhevnikov O.V., Tsykunov M.B., Saltykova V.G., Malakhov O.O. Metody diagnostiki i lecheniia bolezni Pertesa [Methods of Perthes disease diagnosis and treatment]. Materialy 3-go Mezhdunarodnogo Kongressa "Sovremennye Tekhnologii v Travmatologii i Ortopedii” [Proc. $3^{\text {rd }}$ International Congress “Current Technologies in Traumatology and Orthopaedics”]. M., 2006, vol. 2, pp. 395. (in Russian)

24.Plasschaert V.F., Horemans H.L., De Boer L.M., Harlaar J., Diepstraten A.F., Roebroeck M.E. Hip abductor function in adults treated for Perthes disease. J. Pediatr. Orthop. B, 2006, vol. 15, no. 3, pp. 183-189. DOI: 10.1097/01. bpb.0000186645.76697.7a.

25.Schoenecker P. Do We Need Another Gold Standard to Assess Acute Legg-Calvé-Perthes Disease? Commentary on an article by Harry K.W. Kim, MD, MS, et al.: "Perfusion MRI in Early Stage of Legg-Calvé-Perthes Disease to Predict Lateral Pillar Involvement. A Preliminary Study”. J. Bone Joint Surg. Am., 2014, vol. 96, no. 14, pp. e125. DOI: 10.2106/JBJS.N.00353.

26.Manenti G., Altobelli S., Pugliese L., Tarantino U. The role of imaging in diagnosis and management of femoral head avascular necrosis. Clin. Cases Miner. Bone Metab., 2015, vol. 12, no. Suppl. 1, pp. 31-38. DOI: 10.11138/ccmbm/2015.12.3s.031.

27.Geith T., Niethammer T., Milz S., Dietrich O., Reiser M., Baur-Melnyk A. Transient bone marrow edema syndrome versus osteonecrosis: perfusion patterns at dynamic contrast-enhanced MR imaging with high temporal resolution can allow differentiation. Radiology, 2017, vol. 283, no. 2, pp. 478-485. DOI: 10.1148/radiol.2016152665.

28.Mueller D., Schaeffeler C., Baum T., Walter F., Rechl H., Rummeny E.J., Woertler K. Magnetic resonance perfusion and diffusion imaging characteristics of transient bone marrow edema, avascular necrosis and subchondral insufficiency fractures of the proximal femur. Eur. J. Radiol., 2014, vol. 83, no. 10, pp. 1862-1869. DOI: 10.1016/j.ejrad.2014.07.017.

29.Hatanaka H., Motomura G., Ikemura S., Kubo Y., Utsunomiya T., Baba S., Kawano K., Nakashima Y. Differences in magnetic resonance findings between symptomatic and asymptomatic pre-collapse osteonecrosis of the femoral head. Eur. J. Radiol., 2019, vol. 112, pp. 1-6. DOI: 10.1016/j.ejrad.2019.01.002.

30.Flack N.A., Nicholson H.D., Woodley S.J. A review of the anatomy of the hip abductor muscles, gluteus medius, gluteus minimus, and tensor fascia lata. Clin. Anat., 2012, vol. 25, no. 6, pp. 697-708. DOI: 10.1002/ca.22004.

31.Macovei L.A., Rezus E. Anatomical and clinical observations on structural changes of the hip joint. Rev. Med. Chir. Soc. Med. Nat. Iasi., 2016, vol. 120, no. 2, pp. 273-281.

32.Elzanie A., Borger J. Anatomy, Bony Pelvis and Lower Limb, Gluteus Maximus Muscle. Treasure Island (FL), StatPearls Publishing, 2019. Available at: http://www.ncbi.nlm.nih.gov/books/NBK538193/

33.Zacharias A., Green R.A., Semciw A., English D.J., Kapakoulakis T., Pizzari T. Atrophy of hip abductor muscles is related to clinical severity in a hip osteoarthritis population. Clin. Anat., 2018, vol. 31, no. 4, pp. 507-513. DOI: 10.1002/ca.23064.

34.Zacharias A., Pizzari T., English D.J., Kapakoulakis T., Green R.A. Hip abductor muscle volume in hip osteoarthritis and matched controls. Osteoarthritis Cartilage, 2016, vol. 24, no. 10, pp. 1727-1735. DOI: 10.1016/j.joca.2016.05.002.

35.Kovalak E., Özdemir H., Ermutlu C., Obut A. Assessment of hip abductors by MRI after total hip arthroplasty and effect of fatty atrophy on functional outcome. Acta Orthop. Traumatol. Turc., 2018, vol. 52, no. 3, pp. 196-200. DOI: 10.1016/j.aott.2017.10.005.

36.Grimaldi A., Richardson C., Stanton W., Durbridge G., Donnelly W., Hides J. The association between degenerative hip joint pathology and size of the gluteus medius, gluteus minimus and piriformis muscles. Man. Ther., 2009, vol. 14, no. 6, pp. 605-610. DOI: 10.1016/j.math.2009.07.004. 
Genij Ortopedii, Vol. 25, no 4, 2019

37.Diachkova G.V., Korabelnikov M.A., Diachkov K.A. Rentgenograficheskaia i sonograficheskaia kharakteristika iagodichnykh myshts $\mathrm{u}$ bolnykh akhondroplaziei [Roentgenographic and sonographic characteristic of gluteal muscles in patients with achondroplasia]. Meditsinskaia Vizualizatsiia, 2006, no. 4, pp. 91-97. (in Russian)

Received: 27.08.2019

\section{Information about the authors:}

1.Galina V. Diachkova, M.D., Ph.D., Professor, Russian Ilizarov Scientific Center for Restorative Traumatology and Orthopaedics, Kurgan, Russian Federation, Email: dgv_2003@list.ru

2. Mikhail P. Teplenky, M.D., Ph.D., Russian Ilizarov Scientific Center for Restorative Traumatology and Orthopaedics, Kurgan, Russian Federation 3. Konstantin A. Diachkov, M.D., Ph.D., Russian Ilizarov Scientific Center for Restorative Traumatology and Orthopaedics, Kurgan, Russian Federation, Email: dkadoc@mail.ru

4. Tat'iana A. Larionova, M.D., Ph.D.,

Russian Ilizarov Scientific Center for Restorative Traumatology and Orthopaedics, Kurgan, Russian Federation, Email: lar_rad@mail.ru 